\title{
Effects of the proteasome inhibitor bortezomib alone and in combination with chemotherapeutic agents in gastric cancer cell lines
}

\author{
SUNG HWA BAE ${ }^{1}$, HUN-MO RYOO ${ }^{1}$, MIN KYOUNG KIM ${ }^{3}$, \\ KYUNG HEE LEE ${ }^{3}$, JEONG-IM SIN ${ }^{2}$ and MYUNG SOO HYUN ${ }^{3}$ \\ ${ }^{1}$ Division of Hematology-Oncology, Department of Internal Medicine, ${ }^{2}$ Department of Microbiology, Daegu Catholic \\ University College of Medicine; ${ }^{3}$ Division of Hematology-Oncology, Department of Internal Medicine, \\ Yeungnam University College of Medicine, Daegu 705-717, Korea
}

Received April 16, 2007; Accepted November 12, 2007

\begin{abstract}
The proteasome plays a pivotal role in controlling cell proliferation, apoptosis, and differentiation in a variety of tumor cells. Bortezomib is a boronic acid dipeptide derivative, which is a selective and potent inhibitor of the proteasome and has prominent effects in vitro and in vivo against several solid tumors. We examined the anti-proliferative and apoptotic effects of bortezomib in three gastric cancer cell lines (SNU638, MUGC-3 and MKN-28), along with its antitumor combination effects with other chemotherapeutic agents. Tumor cell growth inhibition and apoptosis was measured by MTT assay and FACS analysis, respectively. Apoptosis- and cell cycle-associated protein expression levels were measured by Western blot assay. Bortezomib induced the suppression of tumor cell growth and apoptosis in a dose-dependent manner with an inhibitory dose (ID) $)_{50}$ of approximately $0.5 \mu \mathrm{g} / \mathrm{ml}$ in all gastric cancer cell lines tested. Further combination treatment with cisplatin and docetaxel, in particular with docetaxel displayed dramatically increased tumor cell growth suppression in all three gastric cancer cell lines, as compared to single drug treatment alone. This was concomitant with the induction patterns of apoptotic cells. Bortezomib treatment increased the Bax protein expression. Moreover, combination treatment of bortezomib plus docetaxel resulted in a dramatic increase in the Bax expression. In contrast, Bcl-2 expression was decreased by combination treatment with bortezomib plus docetaxel in SNU638 cells. Finally, bortezomib, docetaxel and to a greater degree bortezomib plus docetaxel increased the expression levels of p27 proteins even without influencing p53 expression levels. Bortezomib has profound effects on tumor cell growth inhibition and induction of apoptosis in
\end{abstract}

Correspondence to: Dr Myung Soo Hyun, Department of Internal Medicine, Yeungnam University College of Medicine, 317-1 Daemyung-dong, Nam-gu, Daegu 705-717, Korea

E-mail: hms@med.yu.ac.kr

Key words: bortezomib, apoptosis, gastric cancer, in vitro, docetaxel human gastric cancer cells, suggesting that bortezomib may be an effective therapeutic drug for patients with gastric cancer. Further combination studies with other chemotherapeutic drugs, in particular docetaxel showing more tumor cell growth inhibition and apoptosis suggest that combining bortezomib with docetaxel might be more effective for displaying tumor cell growth inhibitory effects in gastric cancer cells through regulation of $\mathrm{Bcl}-2, \mathrm{Bax}$ and p27 proteins in vitro.

\section{Introduction}

Despite a declining incidence in many developed countries, gastric cancer remains the second most common cancer in the world (1) and the most common cancer in Korea (2). The prognosis for advanced gastric cancer remains poor. Increasing evidence has shown that combination chemotherapy improves overall survival of the gastric cancer patients compared with the best supportive care in several randomized studies (3-5). However, this extends only median survival by 2-4 months. Therefore, novel strategies are needed in the treatment of advanced gastric cancer.

Several regulatory proteins, such as tumor suppressors, transcription factors and oncogenic proteins are degraded by the proteasome pathway. Proteasome inhibition can cause cellular apoptosis by affecting the levels of various short-lived proteins, resulting in inhibition of NF- $\mathrm{KB}$ activity, an increase in the p53 and Bax protein activity, and accumulation of cyclin-dependent kinase inhibitors, p27 and p21 (6,7). Based on the unique potential for cellular regulation via the ubiquitin proteasome pathway, a number of proteasome inhibitors have been developed and shown to be potently cytotoxic against a variety of cancer cell lines in vitro and in vivo (8).

Bortezomib (N-pyrazinecarbonyl-L-phenylalanine-Lleucine boronic acid; previously known as PS-341 or MLN341 ), a boronic acid dipeptide, is a unique and specific inhibitor of the proteasome pathway (6). Bortezomib inhibits the proteasome pathway rapidly and in a reversible manner by binding directly with the $20 \mathrm{~S}$ proteasome complex and blocking its enzymatic activity. Experimental data have shown that bortezomib has cytotoxic effects in a variety of cancer 
types (6). More recently, bortezomib received accelerated approval from the United States Food and Drug Administration for the treatment of patients with refractory multiple myeloma who failed prior chemotherapy (9). Other proteasome inhibitors, such as the calpain inhibitor, MG132, also inhibit gastric cancer cell growth (10). However, little has been reported of the effect of bortezomib on gastric cancer cells.

Bortezomib also blocks chemotherapy-induced NF- $\mathrm{NB}$ activation, leading to augmentation of chemosensitivity and enhanced apoptosis. Combining proteasome inhibitors with CPT-11 has the significant potential to overcome the chemotherapy resistance in colorectal cancer cell lines (11). Other experimental data have consistently demonstrated the ability of bortezomib to sensitize a variety of cancer cells to the apoptotic effects of diverse chemotherapeutic agents (12-14). In this study we investigated the in vitro antitumor activity of bortezomib in human gastric cancer cell lines and its combination antitumor effects with docetaxel and cisplatin, which are standard drugs in the treatment of advanced gastric cancers.

\section{Materials and methods}

Cell lines and cell culture. Human gastric cancer cell lines (SNU 638, NUGC-3 and MKN-28) were obtained from the Korean Cell Line Bank (Seoul, Korea). The cell lines were grown in RPMI-1640 supplemented with $10 \%$ fetal bovine serum in a humidified atmosphere of $5 \% \mathrm{CO}_{2}$ and $95 \%$ air. All chemical reagents were purchased from Sigma Chemical Co. (St. Louis, MO) unless otherwise specified. Docetaxel (Taxotere, Sanofi Aventis, Seoul, Korea) belongs to the Taxane class of chemotherapy drugs. Docetaxel was generously provided by Sanofi Aventis. Cisplatin was purchased from Ildong Pharm. (Seoul, Korea) and bortezomib (Velcade) was obtained from Millennium Pharmaceuticals (Cambridge, MA). In particular, bortezomib is a dipeptide boronic acid derivative that was developed to specifically inhibit the $26 \mathrm{~S}$ proteasome.

Tetrazolium dye methylthiotetrazole (MTT) cytotoxicity assay. Cell growth was measured by MTT assay. Cells were plated into 96 -well microtiter plates $\left(2 \times 10^{4}\right.$ cells/well $)$ and incubated overnight. Cells were then treated with various concentrations of bortezomib, docetaxel, and cisplatin for 24 and $48 \mathrm{~h}$. Then, $20 \mu \mathrm{l}$ of MTT stock solution $(5 \mathrm{mg} / \mathrm{ml})$ was added into each well and the cells were further incubated at $37^{\circ} \mathrm{C}$ for $4 \mathrm{~h}$. The supernatant was replaced with $200 \mu \mathrm{l}$ of $0.04 \mathrm{M}$ hydrochloric acid in isopropanol to solubilize the formazan products. The absorbance at a wavelength of $595 \mathrm{~nm}$ was measured using a microELISA reader (Bio-Rad, Richmond, CA). The negative control well contained medium only. The experiments were repeated at least 3 times independently.

Flow cytometric detection for cell cycle and apoptosis. The effects of each of the single agents and the combinations on cell cycle arrest and apoptosis were analyzed. Cells were trypsinized and washed in PBS before flow cytometry analysis. For cell cycle analysis, cells were fixed in $70 \%$ ethanol at $4^{\circ} \mathrm{C}$ for $2 \mathrm{~h}$, followed by a wash with PBS. Cells were then stained with propidium iodide/RNase staining buffer (BD PharMingen, San Diego, CA) for $15 \mathrm{~min}$ at room temperature. For apoptosis

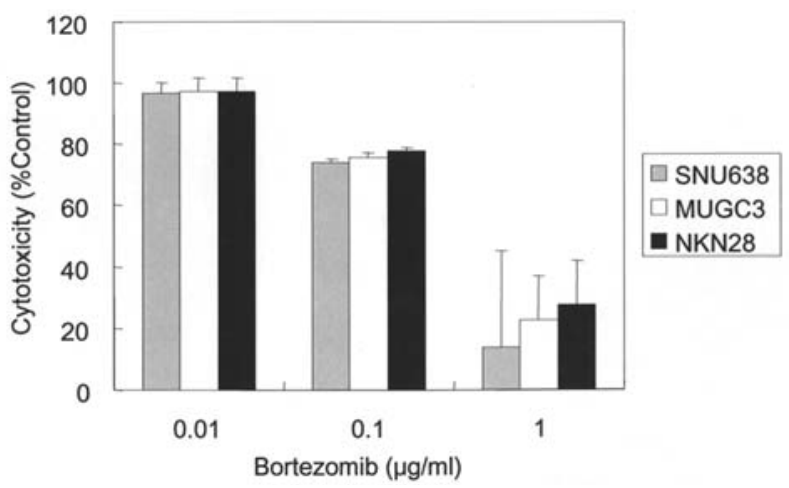

Figure 1. Antitumor effects of bortezomib in SNU638, MUGC3 and NKN28 cell lines in vitro. Three human gastric cancer cell lines were treated with different doses of bortezomib. After $24 \mathrm{~h}$ incubation, the cells were tested for growth inhibition using MTT assay. Values and bars represent OD value means and the SD, respectively. Cytotoxicity (\%) was calculated as OD values of experimental groups/OD values of untreated controls x 100 .

assay, drug-treated cells were trypsinized, washed with PBS, and then resuspended in Annexin-binding buffer (BD PharMingen). The cells were then stained with both Annexin V-phycoerythrin (Annexin V-PE; BD PharMingen) and 7amino-actinomycin (7-AAD; BD PharMingen) for $15 \mathrm{~min}$ at room temperature. The stained samples were measured for the levels of cell cycle arrests and apoptosis using a fluorescence-activated cell sorting caliber bench-top flow cytometer (Becton-Dickinson, Franklin Lakes, NJ). The data were analyzed using FlowJo software (Tree Star Inc., Ashland, OR).

Western blot analysis. Following drug treatments, cells were harvested by trypsin treatment [trypsin $0.25 \% \mathrm{w} / \mathrm{v}, 1 \mathrm{mM}$ ethylenediaminetetraacetic acid (EDTA)]. The cells were lysed for $1 \mathrm{~h}$ at $4^{\circ} \mathrm{C}$ in a lysis buffer containing $150 \mathrm{mM}$ $\mathrm{NaCl}, 1 \%$ Triton X-100, $1 \mathrm{mM}$ phenylmethylsulfonyl fluoride, and $25 \mathrm{mM}$ Tris (ph 7.5). Cell debris was sedimented by centrifugation for $5 \mathrm{~min}$ at $12,000 \mathrm{~g}$, and the supernatants were solubilized for $5 \mathrm{~min}$ at $100^{\circ} \mathrm{C}$ in Laemmli's sodium dodecyl sulfatepolyacrylamide gel electrophoresis (SDSPAGE) sample buffer containing 100-mM dithiothreitol. Protein concentrations of the lysates were determined using a Bio-Rad protein detections assay kit (Bio-Rad Laboratories, Hercules, CA), and 50-100 $\mu \mathrm{g}$ of each sample was separated on a $10 \%$ SDS-PAGE gel by electrophoresis at $100 \mathrm{~V}$ for $90 \mathrm{~min}$. Separated polypeptides were then electrophoretically transferred to 0.2-mm nitrocellulose membranes (Schleicher \& Schuell, Keene, NH) for $75 \mathrm{~min}$ at $30 \mathrm{~V}$. Membranes were blocked for $1 \mathrm{~h}$ in a Tris-buffered saline-Tween (TBS-T; $25 \mathrm{mM}$ Tris, $\mathrm{pH} 8.0,150 \mathrm{mM} \mathrm{NaCl}$ and $0.05 \%$ Tween-20) containing $5 \%(\mathrm{w} / \mathrm{v})$ non-fat dried milk. Blots were probed overnight with primary antibodies and then reacted with secondary antibodies conjugated with horseradish peroxidase. Immunoreactive protein bands were detected by the enhanced chemiluminescence technique (Amersham).

Statistical analysis. Experiments were performed in triplicate and the data were expressed as mean \pm SD. Statistical analysis was performed by the Student's t-test using SPSS11.0 software program. $\mathrm{P}<0.05$ was considered statistically significant. 

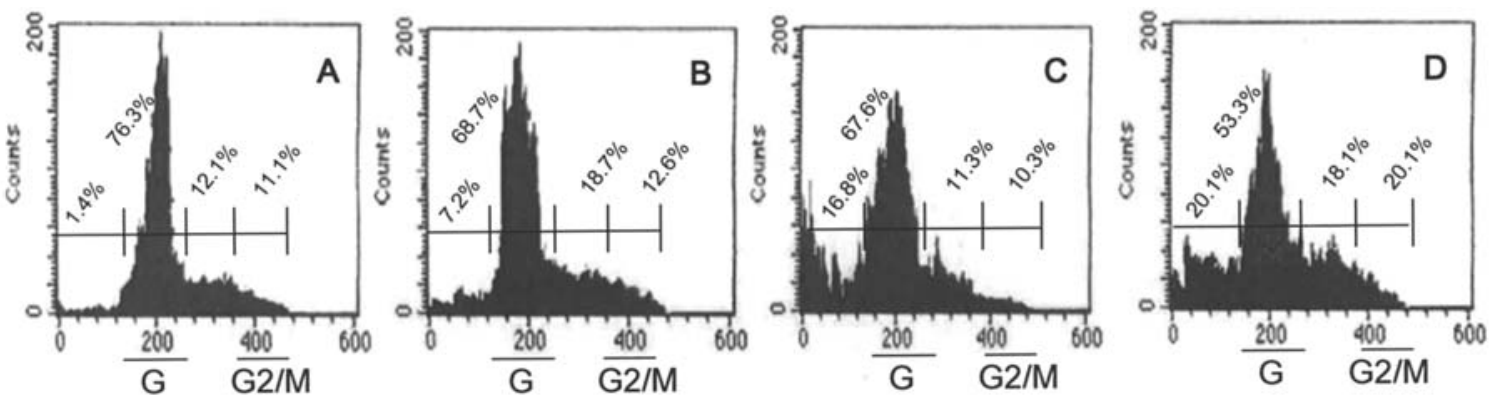

Figure 2. Dose-dependent induction of apoptosis in SNU638 cells by bortezomib. Gastric cancer cells were treated with an increasing dose of bortezomib. After $24 \mathrm{~h}$ incubation, the cells were evaluated for a sub-G1 population by FACS analysis. (A) Untreated controls, (B) bortezomib ( $0.5 \mu \mathrm{g} / \mathrm{ml}),(\mathrm{C}) \mathrm{bortezomib}(1 \mu \mathrm{g} / \mathrm{ml})$ and (D) bortezomib $(5 \mu \mathrm{g} / \mathrm{ml})$.

A
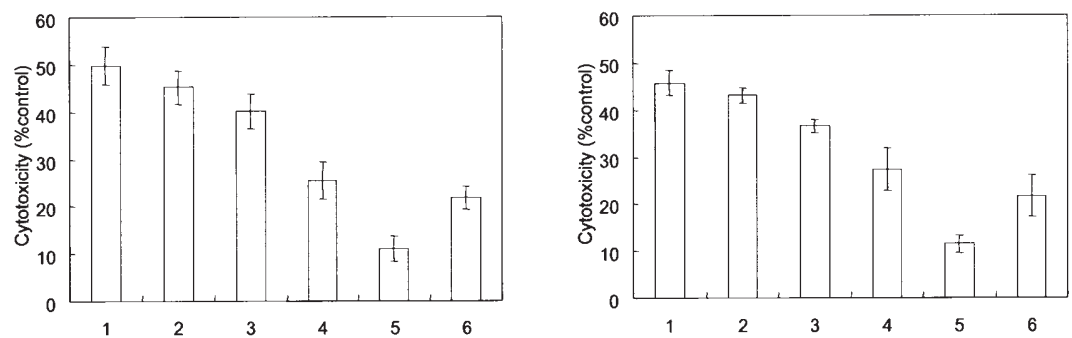

C

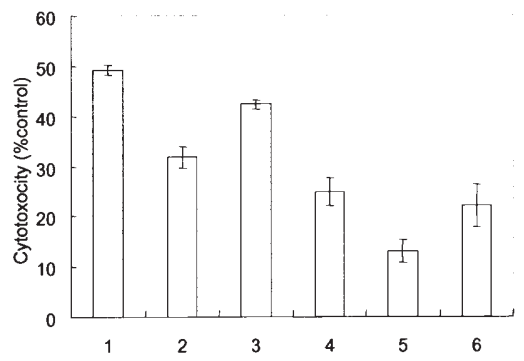

B

Figure 3. In vitro antitumor effects of bortezomib in combination with cisplatin and docetaxel in human gastric cancer cell lines. SNU638 (A), MUGC3 (B) and NKN28 (C). Three human gastric cancer cell lines were treated with bortezomib ( $0.5 \mu \mathrm{g} / \mathrm{ml})$ alone (1), cisplatin (1 $\mu \mathrm{g} / \mathrm{ml})$ alone (2), docetaxel (1 $\mu \mathrm{g} / \mathrm{ml})$ alone (3),

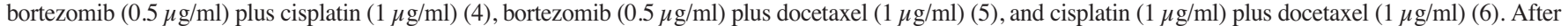
$24 \mathrm{~h}$ incubation, the cells were tested for growth inhibition using MTT assay. Values and bars represent OD value means and the SD, respectively. Cytotoxicity (\%) was calculated as OD values of experimental groups/OD values of untreated controls x 100.

\section{Results}

Bortezomib inhibits cell proliferation in human stomach cancer cell lines. We examined the effect of bortezomib on growth of 3 human stomach cancer cell lines, SNU 638, NUGC-3 and MKN-28 using MTT assay. As shown in Fig. 1, bortezomib treatment for $24 \mathrm{~h}$ resulted in a significant inhibition of tumor cell growth with an inhibitory dose (ID) ${ }_{50}$ of $\sim 0.5 \mu \mathrm{g} / \mathrm{ml}$ for all cell lines tested. We further focused on SNU638 cells to examine the effect of bortezomib on cell cycle arrest. Bortezomib exposure resulted in an increase in the cell population at the sub-G1 phase in a drug dose-dependent fashion, which is indicative of an induction of apoptosis (Fig. 2). In particular, bortezomib treatment at the doses of $0.5,1$ and $5 \mu \mathrm{g} / \mathrm{ml}$ showed $7.21,16.84$ and $20.08 \%$ of cell populations at the sub-G1 phase, respectively. However, untreated control showed $1.35 \%$ at the sub-G1 phase.

Combination treatment using bortezomib plus other chemoherapeutic agents enhanced antitumor effects in vitro. To determine whether bortezomib in combination with other chemotherapeutic agents might increase its antitumor effects, SNU638, NUGC-3 and MKN-28 cells were treated with $0.5 \mu \mathrm{g} / \mathrm{ml}$ of bortezomib $\mathrm{ID}_{50}$ in the presence of cisplatin $(1 \mu \mathrm{g} /$ $\mathrm{ml})$ or docetaxel $(1 \mu \mathrm{g} / \mathrm{ml})$. The dose of cisplatin and docetaxel tested here was found to be approximately (ID) $)_{50}$ in these 3 cancer cell lines (data not shown). When SNU638 cells were treated with bortezomib in combination with cisplatin, cell proliferation was decreased by $74 \%$ compared with untreated controls (Fig. 3A). However, bortezomib plus docetaxel in combination decreased cell proliferation by $89 \%$ compared with untreated controls. Cisplatin plus docetaxel in combination decreased cell proliferation by $78 \%$ compared with untreated controls. This is a dramatic level of decrease in cell proliferation by combination treatments, as compared to single treatment alone. Of the combination regimens, bortezomib plus docetaxel reduced cell proliferation significantly more than bortezomib plus cisplatin $(\mathrm{p}=0.003)$ and cisplatin plus docetaxel ( $p=0.005)$ (Fig. 3A). Similar effects were found in the same treatment in MUG3 and NKN28 cell lines (Fig. 3B 

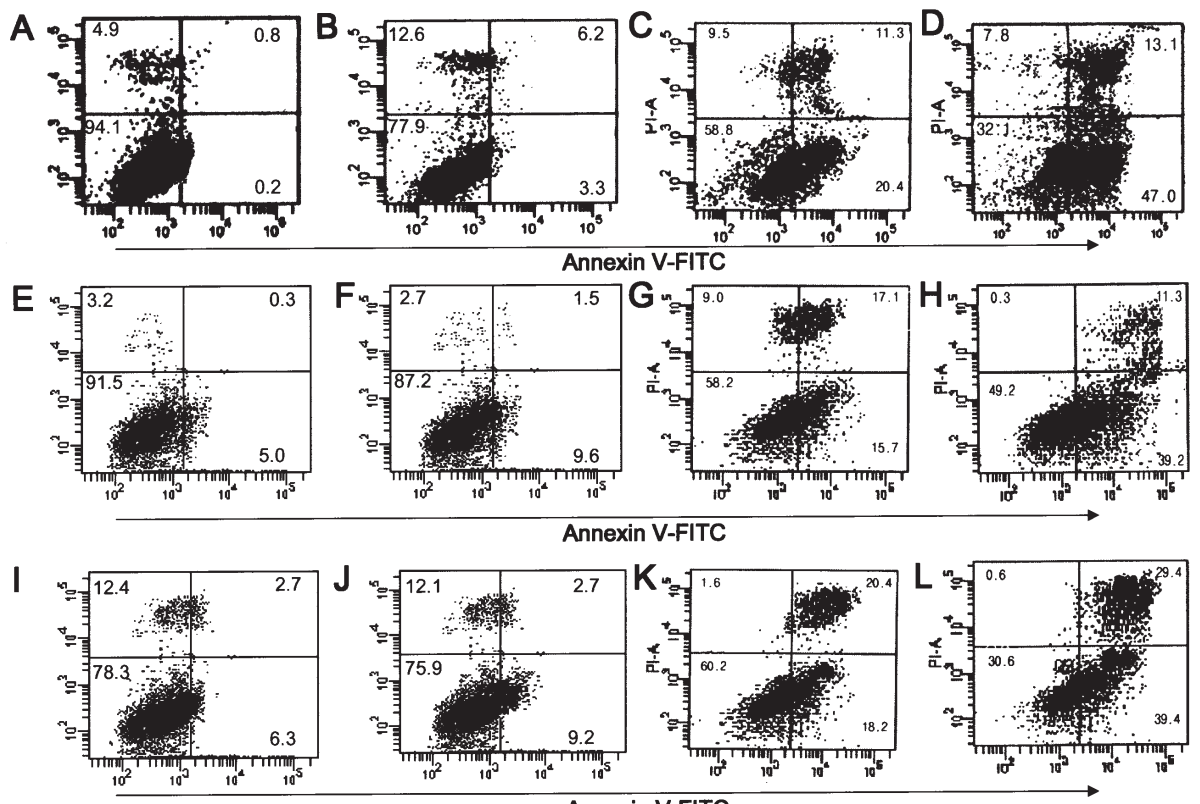

Figure 4. The apoptotic effects of docetaxel plus bortezomib in human gastric cancer cell lines. SNU638 cells were untreated (A), treated with bortezomib $(0.5 \mu \mathrm{g} / \mathrm{ml})$ alone (B), docetaxel $(5 \mu \mathrm{g} / \mathrm{ml})$ alone (C), and docetaxel $(5 \mu \mathrm{g} / \mathrm{ml})$ plus bortezomib $(0.5 \mu \mathrm{g} / \mathrm{ml})(\mathrm{D})$. MUGC3 cells were untreated (E), treated with bortezomib $(0.5 \mu \mathrm{g} / \mathrm{ml})$ alone $(\mathrm{F})$, docetaxel $(5 \mu \mathrm{g} / \mathrm{ml})$ alone $(\mathrm{G})$ and docetaxel $(5 \mu \mathrm{g} / \mathrm{ml})$ plus bortezomib $(0.5 \mu \mathrm{g} / \mathrm{ml})(\mathrm{H})$. NKN28 cells were untreated (I), treated with bortezomib $(0.5 \mu \mathrm{g} / \mathrm{ml})$ alone $(\mathrm{J})$, docetaxel $(5 \mu \mathrm{g} / \mathrm{ml})$ alone $(\mathrm{K})$, and docetaxel $(5 \mu \mathrm{g} / \mathrm{ml})$ plus bortezomib $(0.5 \mu \mathrm{g} / \mathrm{ml})(\mathrm{L})$. After $24 \mathrm{~h}$, cells were reacted with PI and Annexin V-FITC for FACS analysis.

and C). In particular, bortezomib plus docetaxel decreased cell proliferation by $88 \%$ in MUG3 and $87 \%$ in NKN28 cells.

Bortezomib enhanced docetaxel-induced apoptosis. To demonstrate the enhancement of docetaxel-induced apoptosis by bortezomib, 3 cancer cell lines (SNU638, MUG3 and NKN28 cells) were treated with a higher dose of docetaxel $(5 \mu \mathrm{g} / \mathrm{ml})$ showing a significant level of apoptosis induction, followed by concurrent treatment with an $\mathrm{ID}_{50}$ of bortezomib for FACS analysis. As shown in Fig. 4A-D, untreated control, bortezomib $(0.5 \mu \mathrm{g} / \mathrm{ml})$ alone, docetaxel $(5 \mu \mathrm{g} / \mathrm{ml})$ alone and docetaxel $(5 \mu \mathrm{g} / \mathrm{ml})+$ bortezomib $(0.5 \mu \mathrm{g} / \mathrm{ml})$ induced $0.2,3.3,20.4$ and $47.0 \%$ of the SNU638 cells to become apoptotic at $24 \mathrm{~h}$, respectively. Fig. 4E-H showed that untreated control, bortezomib $(0.5 \mu \mathrm{g} / \mathrm{ml})$ alone, docetaxel $(5 \mu \mathrm{g} / \mathrm{ml})$ alone and docetaxel $(5 \mu \mathrm{g} / \mathrm{ml})+$ bortezomib $(0.5 \mu \mathrm{g} / \mathrm{ml})$ induced 5.0, 9.6, 15.7 and $39.2 \%$ of the MUGC3 cells to become apoptotic, respectively. Fig. 4I-L showed that untreated control, bortezomib $(0.5 \mu \mathrm{g} / \mathrm{ml})$ alone, docetaxel $(5 \mu \mathrm{g} / \mathrm{ml})$ and docetaxel $(5 \mu \mathrm{g} / \mathrm{ml})+$ bortezomib $(0.5 \mu \mathrm{g} / \mathrm{ml})$ induced 6.3 , $9.2,18.2$ and $39.4 \%$ of the NKN28 cells to become apoptotic, respectively. This study suggests that docetaxel-induced apoptosis was dramatically enhanced by current addition of bortezomib, which is a 2-fold increase in the level of apoptosis compared with docetaxel treatment alone. This increase also correlates well with the tumor cell growth inhibition we previously observed.

Expression of Bcl-2 and Bax proteins was modulated by bortezomib and docetaxel in SNU638 cells. We next focused on bortezomib and docetaxel in SNU638 cells as they showed the most dramatic combination effects on both tumor cell growth inhibition and induction of apoptosis. To determine the expression levels of the Bcl-2 and Bax proteins, SNU638 cells

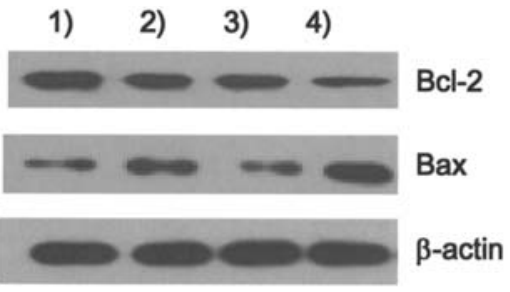

Figure 5. Effects of bortezomib and docetaxel on the expression of apoptosisrelated proteins in SNU638 cells. After treating cells with bortezomib $(1 \mu \mathrm{g} /$ $\mathrm{ml})$, docetaxel $(5 \mu \mathrm{g} / \mathrm{ml})$ and bortezomib $(1 \mu \mathrm{g} / \mathrm{ml})$ plus docetaxel $(5 \mu \mathrm{g} /$ $\mathrm{ml}$ ) for $24 \mathrm{~h}$, total cell lysates were tested for expression of apoptosis-related proteins (Bcl-2, Bax) and $\beta$-actin as a control by Western blot assay. 1), untreated control; 2), bortezomib; 3), docetaxel; 4), bortezomib + docetaxel.

were treated with bortezomib, docetaxel and their combination. As shown in Fig. 5, treatment with either bortezomib $(1 \mu \mathrm{g} / \mathrm{ml})$ or docetaxel $(5 \mu \mathrm{g} / \mathrm{ml})$ alone displayed a slight decrease in the $\mathrm{Bcl}-2$ protein levels as determined by Western blot assay. Furthermore, combination treatment of bortezomib plus docetaxel decreased the $\mathrm{Bcl}-2$ protein expression dramatically more than single treatment alone. In the case of the Bax proteins, however, bortezomib treatment $(1 \mu \mathrm{g} / \mathrm{ml})$ alone resulted in an increased expression of Bax proteins compared with negative controls, whereas docetaxel treatment $(5 \mu \mathrm{g} / \mathrm{ml})$ alone showed no big changes in the Bax protein levels compared with negative controls. However, combination treatment of bortezomib plus docetaxel showed a more dramatic increase in the Bax protein expression compared with controls or either drug treatment alone.

Bortezomib plus docetaxel displayed increased levels of the p27 protein expression but no change in p53 protein expression 


\section{1) 2) 3) 4)}

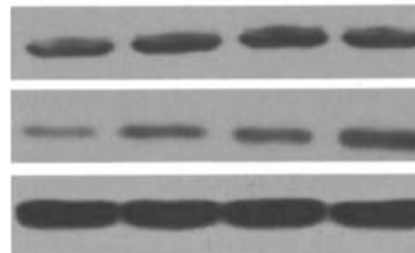

p53

$\beta$-actin

Figure 6. Effects of bortezomib and docetaxel on expression of cell cyclerelated proteins in SNU638 cells. After treating cells with bortezomib $(1 \mu \mathrm{g} /$ $\mathrm{ml})$, docetaxel $(5 \mu \mathrm{g} / \mathrm{ml})$ and bortezomib $(1 \mu \mathrm{g} / \mathrm{ml})$ plus docetaxel $(5 \mu \mathrm{g} / \mathrm{ml})$ for $24 \mathrm{~h}$, total cell lysates were tested for expression of cell cycle-related proteins (p53 and p27) and $B$-actin as a control by Western blot assay. 1), untreated control; 2), bortezomib treatment; 3), docetaxel treatment; 4), bortezomib + docetaxel treatment.

in SNU638 cells. The anticancer effects of bortezomib might be mediated by regulation of the factors that control cell cycle and/or through modulation of the factors that regulate the induction of apoptosis. To determine this, we tested the levels of the cell cycle regulatory proteins, p53 and p27 in SNU638 cells by treatment with bortezomib and docetaxel. As shown in Fig. 6, treatment with either bortezomib or docetaxel alone resulted in a slight increase in the p27 protein expression. Moreover, combination treatment of bortezomib plus docetaxel resulted in a dramatic increase in the $\mathrm{p} 27$ protein expression compared with either single treatment alone. However, treatment with bortezomib alone, docetaxel alone, or bortezomib plus docetaxel failed to show such changes in the $\mathrm{p} 53$ protein expression levels.

\section{Discussion}

In this study, we observed that the proteasome inhibitor bortezomib can inhibit cell proliferation and induce apoptosis in a dose-dependent manner in gastric cancer cell lines. Bortezomib, a boronated proteasome inhibitor, is a new generation proteasome inhibitor and is known to be more potent than the structurally analogous aldehydes (15). In vitro screening data using a panel of 60 human tumor cell lines indicated that bortezomib has significant growth inhibitory activity against a wide variety of tumors (9).

We also observed a dramatic combination effect of bortezomib and docetaxel when they were used together to treat human gastric cancer cells. Our result is in line with previous literature. For example, the synergistic antitumor property of bortezomib with other chemotherapeutic agents in a variety of tumor models, including pancreatic cancer, colon cancer and myeloma, has been reported in vitro and in vivo $(11,16,17)$. Docetaxel is a semi-synthetic taxane with wide activity in a number of solid tumors, including breast, lung and gastric cancer (18).

The ubiquitin-protreasome pathway plays a critical role in the degradation of proteins involved in cell cycle control and tumor growth. Deregulating the degradation of such proteins should have profound effects on tumor growth and apoptosis. Although bortezomib treatment has variable cellular effects, such as inhibition of the ubiquitous survival factor NF- $\mathrm{KB}$ and stabilization of p27 and p21 (19), the specific mediator of chemosensitization remains unclear. In this study on SNU638 cells, bortezomib treatment displayed a slight decrease in the $\mathrm{Bcl}-2$ protein expression. $\mathrm{Bcl}-2$ is a major regulator of apoptosis in response to external stimuli. Docetaxel has been shown to function in part by phosphorylation of $\mathrm{Bcl}-2$, thereby suppressing the normal anti-apoptotic function of this protein (20). Proteasome inhibitor has also been shown to overcome Bcl-2 mediated protection from apoptosis (21). Mortenson et al (22) showed that treatment with bortezomib resulted in decreased transcription of the Bcl-2 promoter, decreased Bcl-2 levels, and induced apoptosis in small cell lung cancer cell lines. However, the Bcl-2 expression was more dramatically decreased by combination treatment with bortezomib plus docetaxel, suggesting that they can down-regulate the Bcl-2 expression in a cooperative manner. The impact of the decreased Bcl-2 levels might be interpreted within the background of other apoptosis-related proteins. In contrast to the Bcl-2 expression, Bax protein, one of the pro-apoptotic proteins, was found to be increasing by bortezomib treatment in SNU638 cells. Moreover, the Bax protein levels were increased to a dramatic degree by combination treatment of bortezomib and docetaxel in SNU638 cells. This result suggests that the two drugs serve to increase the Bax proteins synergistically.

The tumor suppressor p53 protein plays an important role in cell cycle regulation and apoptosis $(23,24)$. In SNU638 cells (p53 mutant forms), bortezomib showed no positive effects on the p53 protein expression levels even in the presence of docetaxel in combination with bortezomib. This is an unexpected finding as we previously observed the induction of apoptosis by bortezomib treatment. Previous studies have suggested that proteasome inhibitors induced apoptosis to inhibit the growth of tumor cells in a p53-independent manner (25-27). Based upon this, it is likely that bortezomib induces tumor cell growth inhibition and apoptosis in a p53independent manner in this p53 mutant gastric cancer cell line. It has been reported that about $35 \%$ of gastric cancers have a p53 mutation (28). This and our findings underscore the importance of utilizing a chemotherapeutic drug, such as bortezomib, which can function independently of the p53 mutational status of the tumors.

The finding that p27 is stabilized by bortezomib or docetaxel treatment suggest that stabilization of this key cell cycle regulatory protein may be involved in the antitumor effects of these molecules when used alone or in combination. Combination treatment, using bortezomib and docetaxel, resulted in an increase in the level of stabilization of p27 when compared with single agent treatment alone. Our result is consistent with previous reports $(11,16)$.

In summary, we have demonstrated that the proteasome inhibitor bortezomib inhibits gastric cancer cell growth through induction of apoptosis. Furthermore, combining bortezomib with docetaxel resulted in both increased cytotoxicity and apoptosis in human gastric cancer cell lines. This was accompanied by increased expression of p27 and Bax proteins but decreased expression of $\mathrm{Bcl}-2$ protein in a $\mathrm{p} 53$ independent fashion. These in vitro data provide the background to support further in vivo studies to confirm the possible benefits of combination treatment using bortezomib and docetaxel. 


\section{References}

1. Pisani P, Parkin DM, Bray F and Ferlay J: Estimates of the worldwide mortality from 25 cancers in 1990. Int J Cancer 83: 18-29, 1999.

2. Shin HR, Jung KW, Won YJ, Park JG and 139 KCCR-affiliated Hospitals: 2002 Annual Report of the Korea Central Cancer Registry: based on registered data from 139 hospitals. Cancer Res Treat 36: 103-114, 2004.

3. Murad AM, Santiago FF, Petroianu A, Rocha PR, Rodrigues MA and Ransch M: Modified therapy with 5-fluorouracil, doxorubicin, and methotrexate in advanced gastric cancer. Cancer 72: 37-41, 1993.

4. Glimelius B, Hoffmann K, Haglund U, Nyron O and Sjoden PO: Initial or delayed chemotherapy with best supportive in advanced gastric cancer. Ann Oncol 5: 189-190, 1994.

5. Pyrhonen S, Kuitunen T and Kouri M: A randomized, phase III trial comparing fluorouracil, epidoxorubicin and methotrexate (FEMTX) with best supportive care in non-resectable gastric cancer. Br J Cancer 71: 587-591, 1995

6. Adams J, Palombella VJ, Sausville EA, Johnson J, Destree A, Lazarus DD, Maas J, Pien CS, Prakash S and Elliott PJ: Proteasome inhibitors: a novel class of potent and effective antitumor agents. Cancer Res 59: 2615-2622, 1999.

7. Almond JB and Cohen GM: The proteasome: a novel target for cancer chemotherapy. Leukemia 16: 433-443, 2002.

8. Drexler HC, Risau W and Konerding MA: Inhibition of proteasome function induces programmed cell death in proliferating endothelial cells. FASEB J 14: 65-77, 2000.

9. Twombly R: First proteasome inhibitor approved for multiple myeloma. J Natl Cancer Inst 95: 845, 2003.

10. Fan XM, Wong BC, Qang WP, Zhou XM, Cho CH, Yuen ST, Leung SY, Lin MC, Kung HF and Lam SK: Inhibition of proteasome function induced apoptosis in gastric cancer. Int $\mathrm{J}$ Cancer 93: 481-488, 2001.

11. Cusack JC, Liu R, Houston MA, Abendroth K, Elliott PJ, Adams J and Baldwin AS: Enhanced chemosensitivity to CPT-11 with proteasome inhibitor PS-341: implications for systemic NF-кB Inhibition. Cancer Res 61: 3535-3540, 2001.

12. Bold RJ, Virudachalam S and McConkey DJ: Chemosensitization of pancreatic cancer by inhibition of the $26 \mathrm{~S}$ proteasome. J Surg Res 100: 11-17, 2001.

13. Hideshima T, Richardson P, Chauhan D, Palombella VJ, Elliott PJ, Adams J and Anderson KC: The proteasome inhibitor PS-341 inhibits growth, induces apoptosis, and overcomes drug resistance in human multiple myeloma cells. Cancer Res 61: 3071-3076, 2001.

14. Cusack JC: Rationale for the treatment of solid tumors with the proteasome inhibitor bortezomib. Cancer Treat Rev 29: 21-31, 2003.
15. Ling YH, Liebes L, Jiang JD, Holland JF, Elliott PJ, Adams J, Muggia FM and Perez-Soler R: Mechanisms of Proteasome inhibitor PS-341-induced G2-M-phase arrest and apoptosis in human non-small cell lung cancer cell lines. Clin Cancer Res 9: 1145-1154, 2003.

16. Nawroki ST, Sweeney-Gotsch B, Takamori R and McConkey DJ: The proteasome inhibitor bortezomib enhances the activity of docetaxel in orthotopic human pancreatic tumor xenografts. Mol Cancer Ther 31: 59-70, 2004.

17. Ma MH, Yang HH, Parker K, Manyak S, Friedman JM, Altamirano C, Wu ZQ, Borad MJ, Frantzen M, Roussos E, Neeser J, Mikail A, Adams J, Sjak-Shie N, Vescio RA and Berenson JR: The proteasome inhibitor PS-341 markedly enhances sensitivity of multiple myeloma tumor cells to chemotherapeutic agents. Clin Cancer Res 9: 1136-1144, 2003.

18. Montero A, Fossella F, Hortobagyi G and Valero V: Docetaxel for treatment of solid tumours: a systematic review of clinical data. Lancet Oncol 6: 229-239, 2005.

19. Rajkumar SV, Richardson PG, Hideshima T and Anderson KC: Proteasome inhibition as a novel therapeutic target in human cancer. J Clin Oncol 23: 630-639, 2005.

20. Haldar S, Basu A and Croce CM: $\mathrm{Bcl} 2$ is the guardian of microtubule integrity. Cancer Res 57: 229-233, 1997.

21. You SA, Basu A and Haldar S: Potent antitumor agent proteasome inhibitors: a novel trigger for $\mathrm{Bcl}-2$ phosphorylation to induce apoptosis. Int J Oncol 15: 625-628, 1999.

22. Mortenson MM, Schlieman MG, Virudachalam S, Lara PN, Gandara DG, Davies AM and Bold RJ: Reduction in BCL-2 levels by $26 \mathrm{~S}$ proteasome inhibition with bortezomib is associated with induction of apoptosis in small cell lung cancer. Lung Cancer 49: 163-170, 2005.

23. Kuerbitz SJ, Plunkett BS, Walsh WV and Kastan MB: Wild-type p53 is a cell cycle checkpoint determinant following irradiation. Proc Natl Acad Sci USA 89: 7491-7495, 1992.

24. $\mathrm{Wu} \mathrm{X}$ and Levine AJ: p53 and E2F-1 cooperate to mediate apoptosis. Proc Natl Acad Sci USA 91: 3602-3606, 1994.

25. Shinohara K, Tomioka M, Nakano H, Tone S, Ito H and Kawashima S: Apoptosis induction resulting from proteasome inhibition. Biochem J 317: 385-388, 1996

26. Kitagawa H, Tani E, Ikemoto H, Ozaki I, Nakano A and Omura S: Proteasome inhibitors induce mitochondria-independent apoptosis in human glioma cells. FEBS Lett 443: 181-186, 1999.

27. Wagenknecht B, Hermisson M, Eitel K and Weller M: Proteasome inhibitors induce p53/p21-independent apoptosis in human glioma cells. Cell Physiol Biochem 9: 117-125, 1999.

28. Uchino S, Noguchi M, Ochidai A, Saito T, Kobayashi M and Hirohashi S: p53 mutation in gastric cancer: a genetic model for carcinogenesis is common to gastric and colorectal cancer. Int $\mathbf{J}$ Cancer 54: 759-764, 1993. 